\title{
The global context for Federation: The spread of nationalism and the triumph of the nation-state
}

\author{
Henry Ergas ${ }^{1}$
}

\section{Abstract}

Liberal nationalism's culminating moment, the European revolutions of 1848 , ended in utter failure. A movement of intellectuals entirely lacking a popular base, the principle of nationality experienced a far-reaching illiberal turn. By the 1890s the world was awash in deeply illiberal, and often positively repellent, nationalisms. Britain itself, however, seemed an exception. But an almost endless list of new fears had emerged and moved to the centre of her politics. Britain was, in Joseph Chamberlain's evocative phrase, a 'weary titan', staggering 'under the too vast orb of its fate'. The time predicted by Herman Merivale seemed to have come. As Under-Secretary of State at the Colonial Office from 1847 to 1860, he had foreseen the day when the Empire would have to prove flexible enough to absorb the 'great Australian Republic which probably is to be'.

\section{The background}

All of us alive were born into a world of nation-states. We learned, generally very early on, that the right answer to the question 'Where are you from?', particularly when posed overseas, was (say) 'Australia', rather than the street address of the hospital at which we were born.

$1 \quad$ Ergas.henry@gmail.com. 
By the time we reached adult life, it would have seemed entirely natural to us that being Australian, rather than, say, Austrian, comes with a package of attitudes, expectations, rights and obligations that is common to Australians and not to Austrians.

And we would also have expected that anyone we met would know how to answer the 'Where are you from?' question in much the same way as we did, and would have, in his or her mind, a package of attitudes, expectations, rights and obligations that was shared with his or her co-nationals and differed from the mental package of other nationalities.

But none of that would have been the case at the beginning of the eighteenth century. Instead of taking a standard form, polities came in a bewildering array of shapes and sizes, including city-states, principalities, composite monarchies that ruled over geographically separate territories, agrarian military domains, and empires, as well as combinations of some or all of those. While there would have been many ways of answering the 'Where are you from?' question, none of them would have invoked the concept of nationality. And although attitudes, expectations, rights and obligations naturally varied greatly from place to place, they were not standardised within national borders in the way they are today.

That was, to some extent, still true when the Commonwealth of Australia was formed in 1901. But even though the triumph of the nation-state as virtually the only form of polity did not come until the end of the First World War-with the collapse of the great land empires and the affirmation by that odd couple, V.I. Lenin and Woodrow Wilson, of that even odder notion, national self-determinationthe ascendancy of the nation-state was, by the time of Federation, unmistakable. And integral to that ascendancy was the seemingly irresistible rise of what, in the nineteenth century, was known as the principle of nationality.

That principle, although variously expressed, involved three central elements. The first, which was asserted as an empirical proposition, stated that humanity is divided into nations. The second, which was normative in character, said that nations deserve recognition and respect, allowing their unique attributes to flourish. And the third, which derived an aspiration from the two that preceded it, claimed that nations could only obtain the recognition and respect to which they were entitled if they were autonomous, which usually meant independence and the sovereignty that came with it.

Broadly speaking, nationalism was the translation into the political sphere of the principle of nationality. But nationalism was obviously much more than a political philosophy: it defined an ideal and shaped an outlook on the world; it formed the basis for an urgent call to action; it demanded of its adherents a loyalty and commitment to the cause that could, and in many cases did, involve the sacrifice of life itself. 
Nationalism might, in those respects, be viewed as a religion; indeed, the great German political theorist Carl Schmitt considered it to be a secularised version of faith. However, this was a religion that was not founded on any sacred text, lacked any formal structure and never vested authority in any high priests; all it had was a master-concept - the nation — which admitted of a vast range of uses and conceptions. Plastic and polymorphic, its shape evolved over time and space, in ways that have made the search for a unified theory of nationalism a quest for a will-o-the-wisp, invariably leading those who have engaged in it to their doom.

It is, nonetheless, possible to trace, at least in broad outline, the forms it took and the elements that combined as it grew and mutated over the decades leading up to the debate on Australian Federation. How did the principle of nationality develop in the course of the long nineteenth century, which opened with the 'age of revolutions' and ended with the cataclysm of the First World War? What kind of nationalismor, as will be clear, of nationalisms - defined the broader world in which the debate between those who favoured Federation and those who opposed it occurred? These are the questions that this article, in providing part of the context to the broader assessment of Federation, seeks to address.

In addressing them, it would scarcely be possible to start at the beginning, which would, at a minimum, require us to go back to late medieval Europe; yet there is a great deal of truth in Chaucer's proverb that 'Out of the old fields must spring and grow the new corn'. In this case, the old fields were rich in seeds, and much ploughing had been done, well before our narrative begins toward the end of the eighteenth century.

The idea of a 'nation' had long existed, but it was not at all well-defined; typically, it referred fairly narrowly to political elites, rather than encompassing the people who inhabited a particular territory. However, what had come into progressively sharper focus was the concept of 'the state' as a form of public power separate both from the ruler and the ruled, and which exercised the supreme political authority within a defined territory. By the close of the sixteenth century, that concept lay at the heart of political thinking; and it gained crucial recognition in the settlements, however tenuous they proved to be, of the religious wars that had torn the German lands apart in the aftermath of the Reformation. First the Treaty of Augsburg, in 1555, and then the more important and lasting Treaty of Westphalia in 1648, bundled together state and territory, with the principle of 'cuius regio eius religio' - whosoever the state, his the religion - vesting in the prince of each treaty state the authority to determine whether the principality would or would not retain 'the old religion'. The Westphalian peace thereby gave formal recognition to an interstate system based on territorially defined sovereigns. 
The Treaty of Westphalia had many consequences, of which two are worth mentioning here. To begin with, it intensified the focus on the geography of power, and notably on frontiers. Until then, these had usually been very poorly demarcated; now, much greater emphasis was placed on determining exactly where one state ended and another began. Before the mid-sixteenth century, frontiers rarely featured on maps: by 1570, when Abraham Ortelius produced the first modern atlas, about half of its maps located borders, while Joan Blaeu's magnificent Theatre du monde ou novel atlas, which appeared in 1635, marked the frontiers on almost four-fifths. This attention to frontiers was distinctive: Chinese maps, for example, lacked it almost entirely. And it was accompanied by increased concentration on internal delineation as well, with the emergence in that period of the first modern territorial surveys and cadastres.

At the same time, the Westphalian peace, as well as the wars that preceded it, drew attention to crucial questions about states and the relations between them-for instance, how did a polity become a 'state'? Who decided, and what determined, the rights and obligations that status entailed? Those questions were central to a bevy of Protestant thinkers, whose ability to practice their faith depended on the territorial integrity of the small and perpetually threatened polities that had adopted the new religions of Lutheranism and Calvinism. Central among those thinkers were the Dutch prodigy Hugo Grotius, who wrote in the first half of the sixteenth century, the German scholar Samuel von Pufendorf (1632-94) and the Swiss international lawyer Emer (Emmerich) de Vattel, whose masterpiece, The Law of Nations, appeared in 1758; between them, they cemented the notion of international society as a system of states that recognised each other as equals entitled to live in peace.

These ideas were in the air; but they, and many others, were brought into entirely new alignment by two events that - quite understandably—appeared to contemporaries as extraordinary, indeed, revolutionary: the American Declaration of Independence and the French Revolution.

\section{The American Declaration of Independence}

But before turning to the decision of the American colonists to declare independence, it is helpful to know that historically, the word 'revolution', when used in a political context, did not refer to a dramatic new beginning; on the contrary, it meant a restoration, a return to a prior state of affairs.

Thus, the word was first used not when what we would call a revolution broke out in England and Cromwell rose to the first revolutionary dictatorship, but in 1660, after the overthrow of the Rump Parliament and the restoration of the monarchy. The word was used in precisely the same sense in 1688, when the Stuarts were expelled and power was transferred to William and Mary. The 'Glorious Revolution', 
the event through which the term paradoxically found its place in political and historical language, was not thought of as a revolution in the modern sense at all, but as a restoration of monarchical power to its former righteousness and glory.

There are good reasons to believe that the founders of the United States conceived of what they were doing in much the same way, at least initially. Their original goal was not independence but to free themselves from control by a parliament they thought was dominated by interests inimical to their own; they would, it seems, have been content to be self-governing subjects of the Crown, as they claimed they had been when the colonies were established. But they knew their Vattel, which, as Benjamin Franklin told the editor of The Law of Nations in December 1775, 'has been continually in the hands of our Congress, now sitting' (Scott, 1916, p. 1a). And it was clear from Vattel that Congress could only legitimately 'levy war' and 'contract alliances' against Great Britain, as it was determined to do, if it acted on behalf of a sovereign state.

Thomas Paine influentially explained the situation in Common Sense, which appeared in January 1776. Only independence according to the 'custom of Nations' would permit a mediator to negotiate peace between the United States and Great Britain, as only states could make or secure treaty commitments from each other. Equally, foreign alliances could not be obtained without it. And unless the United States was recognised as an independent state, the Americans would be mere rebels, as George III had declared the colonists to be in August 1775, rather than waging a war. For all of those reasons, Paine concluded, it was essential for a 'manifesto to be published, and despatched to foreign Courts'; failing that, 'the custom of all Courts is against us, and will be so, until by an Independance [sic], we take rank with other Nations' (Paine, 1776).

All that was clearly reflected in the Declaration of Independence's famous opening sentence, which asserts that the colonists' goal is to 'assume among the powers of the earth the separate \& equal station to which the laws of nature and of nature's God entitle them'. And it was that 'separate \& equal' station-that is, the recognition of the United States as representing sovereign entities— that the British eventually conceded.

The American Revolution was not the first successful secession of a province from an imperial monarchy: 'the Dutch revolution' of the late sixteenth century held that honour, as America's revolutionaries often noted. But there is no doubt that the Declaration of Independence was the first to identify sovereignty with national independence. It successfully claimed for the former colonies the two essential characteristics that form the constitutive principle of states and give them their external shell: imperium, that is, final and absolute authority over a political community; and majestas, which is the dignity and respect that authority commands 
and which entitles it to be a state among states—endowed, as Vattel put it, with a 'perfect equality' to other states, including in its right to be left to the 'peaceful enjoyment' of its liberties.

The Declaration itself, and the colonists' achievement in realising their goal, had an enormous impact. When Britain recognised American sovereignty in 1783, Edmund Burke immediately noted that a momentous event had occurred. 'A great revolution has happened', he wrote:

a revolution made, not by chopping and changing of power in any one of the existing states, but by the appearance of a new state, of a new species, in a new part of the globe. It has made as great a change in all the relations, and balances, and gravitation of power, as the appearance of a new planet would in the system of the solar world. (Burke, 1852, p. 453)

Overall, the Americans had proved that sovereignty could be acquired through an act of will, thus establishing the bases for a world of nation-states born through deliberate political action. The reverberations did not take long to make themselves felt. The Haitian Declaration of Independence came in 1804; and while it failed, it was followed by the Venezuelan Declaration of Independence in 1811, which copied significant elements of its American counterpart word for word. That set off a chain of declarations of independence throughout Central and South America with the result that by 1844 , the entire region was populated by self-formed nation-states. It was also the American Declaration that inspired the Greek War of Independence, which began in 1821 and served as a model for the nationalist movements that, over the course of the nineteenth century, swept the Balkans and central Europe, helping to destroy the great Ottoman and Austro-Hungarian empires. And even the united Māori tribes of the North Island of New Zealand signed a 'Declaration of the Independence of New Zealand' in 1835, albeit mainly so as to allow British penetration of the islands before the French could lay claim to them.

\section{The French Revolution}

While the American Declaration of Independence unleashed the immense 'change in all the relations, and balances ... of power' between states that Burke predicted, the tumultuous process that began in France in 1789 dramatically altered the relations and balances of power within states, ultimately redefining the state itself.

To say that is not to ignore the important elements of continuity, which Tocqueville famously stressed, between the changes that were already underway in the Ancien Regime and those that followed its fall; nor is it to deny that many of the states that did not experience anything approaching the French cataclysm were nonetheless in the throes of immense transformations that ultimately reshaped their social and 
political life. But what happened in France was the first attempt to consciously shape an entirely new world by tearing down the old order and putting a completely different order in its place. It was, to that extent, the first modern revolution; and it was clearly the modern meaning of the term that François Alexandre Frédéric, duc de la Rochefoucauld-Liancourt, intended when, on the very night of the fall of the Bastille, he warned Louis XVI that 'Sire, this is not a revolt, it is a revolution'.

The French Revolution was a blood-soaked affair, and its causes, course and consequences remain the subject of intense historical debate. But just as the American Declaration of Independence irreversibly conjoined the notion of sovereignty to that of national independence, so the French Revolution, and the successive constitutions it gave rise to, developed a coherent bundle of concepts that eventually became the backbone of our conception of the nation-state. Four elements of that bundle of concepts are especially relevant: the nation, which was seen as the locus of sovereignty; the citizens, who were its members and comprised 'the people'; rights and duties, which were the privileges and obligations attached to citizenship; and the state, which was the concrete form through which sovereignty was expressed and which gave the rights and duties of citizens their substance.

Each of those concepts had deep antecedents in European political thought, each acquired new meaning in the course of the revolution and each was to have far-reaching effects. But while they now seem entirely obvious, they have their subtleties, and none more so than that of sovereignty.

We have already encountered that concept as involving the external casing of the state; what makes it an equal in international law to other states that recognise its authority over a defined territory. But France had long enjoyed that protective shell. The concept of sovereignty as it was used in the French Revolution was therefore viewed in very different terms: not as the external recognition of authority but as the ultimate source of the state's domestic legitimacy.

And at heart of the concept as it was used in the French context was the notion that a fundamental distinction had to be drawn between the sovereign on the one hand and the government or the ruler on the other. That distinction was not a new one: it had already been made by Jean Bodin in the sixteenth century and by Thomas Hobbes a century later. But Jean-Jacques Rousseau placed it at the centre of his work, and made it serve an entirely new end. That Rousseau regarded it as crucial is beyond doubt: he warned readers of The Social Contract that mastering it required careful attention; and in the eighth of his Letters Written from the Mountain, written in 1764 in defence of The Social Contract and of Emile, he declared that:

Up to the present the democratic Constitution has been poorly examined. All those who have spoken about it either did not know it, or took too little interest in it, or had an interest in presenting it in a false light. None of them have sufficiently distinguished the Sovereign from the Government. (Rousseau, 2001, p. 257; emphasis added) 
What he meant, simply put, was that government could not authorise itself; rather, its authority derived from an ultimate source, and it was that source which was the sovereign. As a result, that sovereign was not constrained by whatever arrangements of government happened to be in place; on the contrary, it could alter them as it saw fit. And unless the arrangements were approved by the sovereign, they lacked legitimacy.

It is somewhat paradoxical that the canonical form of this proposition, and of its institutional implications, were elaborated by a French Catholic clergyman, Emmanuel Joseph Sieyès (1748-1836), most commonly known as the abbé Sieyès, who, when he was asked what he had done during the revolution, laconically replied that he had survived. But few of the thinkers caught up in the upheaval had greater or more enduring impact.

Sieyès set out three propositions. The first was that there was a meaningful entity called 'the nation', which broadly emerged from the shared history of a community and which was pre-political, in the sense that it existed independently of the political arrangements that prevailed at any time. The second was that the nation so defined was the ultimate source of authority and hence was the sovereign, with the power to constitute the form of government. And the third was that that 'constituent power' - the power to 'constitute' the state-was logically prior to and separate from the 'constituted power' (i.e. the government), whose concrete form it determined.

There was, in other words, a difference, which ought to be reflected in institutional terms, between the act of defining, modifying and ratifying a constitution, which necessarily required the approval of the constituent power (i.e. the nation); and the task of legislating within the framework of the constituted power, which could be delegated to representatives.

Sieyès's notion of a constituent power on the one hand, and a constituted power on the other, eventually provided the conceptual framework for modern constitutionmaking; no less significantly, it specified a mechanism by which revolutionary change-the transition from one order to another-could, at least in theory, be legitimated. And by tying ultimate sovereignty to 'the nation', understood as a historical community, it both made the nation foundational and vested each nation with the authority to determine its own political future.

Of course, the revolution did much more for the cause of nationalism than just elaborate a theory of the nation as a pre-political sovereign. It largely created, and certainly cemented, the idea that the nation had a collective will, and that that will could be determined, separately from the ordinary electoral processes, through referendums - that is, through direct appeals to the people as a whole. It put in place the first laws that defined and circumscribed citizenship, granting it to some while depriving those who were judged to be 'enemies of the people' of its rights 
and protections. It pioneered mass conscription, creating an army that mirrored and embodied the nation and whose leadership was based on merit, rather than on inherited status. And it developed the panoply of symbols that came to define a nation, including the national anthem, with the Marseillaise-which calls on children of the patrie to water the nation's furrows with the blood of the enemybeing undoubtedly the most stirring of its genre.

\section{Romanticism and the Volk}

The nation was therefore at the centre both of the French Revolution's theory and of its practice. The Revolution's grim denouement might therefore have brought the career of the principle of nationality to an ignominious end. It did no such thing.

That was at least partly because the mayhem that the revolution and then the Napoleonic Empire spread throughout Europe gave new impetus to thinking that was already underway, albeit it in embryonic form, when the revolution began. Particularly important was the somewhat inchoate movement later known as Romanticism, which started as a reaction to the Enlightenment's overwhelming emphasis on reason. To point to the Enlightenment's emphasis on reason is not to suggest that its great thinkers, most notably Kant, regarded human reason as omniscient; on the contrary, Kant's program was to derive what could be derived 'within the limits of reason', limits that he repeatedly stressed. What is true, however, is that the Enlightenment viewed reason as an innate capacity all humans shared. Because it was everywhere the same, the differences between peoples were inherently transient, and overcoming them was both feasible and desirable.

Assaulting that proposition was the life's work of Johann Gottfried Herder (17441803), who had been Kant's student. Herder was a complex thinker, whose theories are readily caricatured; but his influence on German culture ran wide and deep, initiating movements that range from the study of folklore (which he famously did in tandem with Goethe, collecting German folksongs in Alsace), to that of linguistics and of the philosophy of history.

The crucial point here is the weight he placed on, and the sophistication he brought to, the notion of a 'Volk'. Redolent with meanings, this is not an easy term to translate. In his Anthropology from a Pragmatic Point of View (1797), Kant defined the term, with considerable reticence and even greater vagueness, as meaning 'a multitude of human beings united in a region, in so far as they constitute a whole' (2006, p. 154; emphasis added). In contrast, Herder, in his Ideas for the Philosophy of the History of Humanity (1784/91) portrayed the Volk as a natural phenomenon, writing that 'Nature raises families; the most natural state is therefore also one people, with one national character [which is] as much a plant of nature as a family, only with more 
branches' (2004, p. 128). Herder did not mean by that a Volk could be found in nature; rather, he meant that it developed organically, much like the growth of a forest.

For Herder, a Volk was therefore an entity that had to be defined relationally as the social aggregate that produces a clearly delineated culture and collection of customs. That culture and collection of customs were not the product of intentional human design; rather, they were the manifestation, or working out, of the spirit of the people, or Volksgeist. And underpinning the Volksgeist was a people's language, which, having evolved over the centuries, bore the marks of generations of experience and transmitted to each new generation a kind of coded history of the sufferings and joys of the nation.

But Herder did not merely believe that language was the essential attribute of each Volk: he approved of the resulting divisions of mankind. The variety of languages cut communities off from each other, forcing them to develop their own unique cultures and protecting them from much of the corruption that arises, Herder believed, from the temptation to slavishly imitate foreigners.

In arguing that case, Herder was no bigot; on the contrary, he made it clear that the diversity of languages and cultures was an integral part of the heritage of mankindand it is perhaps fitting that he coined the term 'nationalism', using it as a pejorative that was synonymous with prejudice and loutishness. Whether Johann Gottlieb Fichte (1762-1814), who translated Herder's basic notion of cultural distinctiveness into a political program, showed the same broadmindedness is more controversial.

An immensely original and sophisticated philosopher, Fichte was capable of being as incomprehensible as he was brilliant, perhaps inaugurating a great German tradition in that respect. When in 1801 he tried to explain the basic elements of his thought in a tract that was somewhat comically named 'A Crystal Clear Report to the General Public Concerning the Actual Essence of the Newest Philosophy: An Attempt to Force the Reader to Understand', he did not succeed in making things any better. But unlike his post-Kantian metaphysics, his contributions to nationalism were all too straightforward, and proved far more dangerous than Fichte, who was a committed humanist, seemed to realise.

Those contributions were crafted in the wake of Fichte's bitter disappointment at the failure of the French Revolution to live up to its lofty values of liberty, equality and fraternity, and reflected his belief that realising those values was now the historic task of a German 'nation'. But no such polity existed at the time; Fichte's goal was to motivate its coming into being.

In doing so, he began by acknowledging the French doctrine that the world has been constructed to accommodate nation-states: 'Certain parts of the earth's surface, together with their inhabitants, are visibly destined by nature to form 
political entities' (Fichte, quoted in Reiss, 1955, p. 94). But while he acknowledged that doctrine, he could hardly accept it, as the 'natural borders' defined by the Pyrenees, the Alps and the Rhine appeared to give the French a large slice of what he regarded as Germany. So as to adapt the concept of natural borders to the circumstances of a featureless plain in the centre of Europe, he developed Herder's cultural nationalism into a doctrine of 'inner frontiers'. 'Those who speak the same language', he wrote, 'are linked together, before human intervention takes a hand, by mere nature with a host of invisible ties; they understand each other and are capable of communicating more and more closely with one another, they belong together, they are by nature one indivisible whole'.

Fichte thereby equated the 'natural' nation with the language group. But he went much further than that, asserting that the natural nation not only had a right and obligation to exist, but also to protect itself; moreover, that imperative was especially strong for the Germans, who, being 'honest, serious, sober', readily fell victim to foreign intrigue.

Indeed, it was only because 'foreign cunning easily outmatched German simplicity and credulity' that Germany was not a united country: having found 'German valour useful for waging their wars, and German hands useful for seizing loot from their rivals', the perfidious French had 'made use of the division of opinions which had arisen in Germany on account of the religious controversies, in order to divide artificially this representative microcosm of the whole of Christian Europe, from being an innate organic unit, into separate independent parts'.

Redressing this did not merely require German unification; it also required that the unified entity form a 'closed commercial state'. 'Only the scholar and the creative artist', he opined, with a bow to academics such as himself, 'have reason to travel outside the closed state. Foreign trade should no longer be permitted for those who feel merely a leisured curiosity and a desire for diversion to carry their boredom about through all lands'.

\section{Liberal nationalism}

Fichte's Addresses to the German Nation, which set these ideas out in lectures delivered at the university of Berlin in 1807-08, eventually acquired iconic status as the first and arguably clearest formulation of German cultural or ethnic nationalism. And it is apparent that the lectures expressed a distrust of foreigners, which lent itself both to chauvinism and to the demonisation of 'the enemy within'. But they had little impact at the time; instead, Herder's and Fichte's emphasis on a 'natural nation' was taken up by nationalists whose political program was unassailably liberal. 
Best known among those liberal nationalists were Adam Mickiewicz in Poland, Lajos Kossuth in Hungary and especially Italy's Giuseppe Mazzini. Although they were not systematic thinkers, their prolific writings synthesised the marriage between sovereignty and independence that the Americans had achieved, with that of sovereignty, citizenship and rights and duties that had come out of the French Revolution. Great admirers of Britain, their goal was to secure national independence and within its protective shell, construct constitutional regimes based on the rule of law.

These men were intellectuals and political activists, with their activism forcing them to spend much of their lives in exile. Of the three, Mazzini had by far the greatest resonance. Idolised by many, his 'Young Italy' movement was imitated by partisans of national independence around the world, and his works were eagerly read in places as remote as Sydney, Bombay and Shanghai.

For Mazzini, national independence and self-determination were crucial to allow each people to achieve its potential; as they did so, they would lay the foundations for a gradual move toward a united world. Although there is no reason to believe that he was familiar with Kant's famous essay on Perpetual Peace: A Philosophical Sketch (1795), he shared its commitment to cosmopolitanism as a moral ideal, declaring in 1847 that 'We are all cosmopolitans, if by cosmopolitanism we understand the love and brotherhood of all, and the destruction of all barriers which separate the Peoples' (quoted in Varouxakis, 2018, p. 164). But while that was the ultimate goal, the nation-state was an indispensable stepping-stone.

Perhaps unsurprisingly, these views appealed to no less a liberal than John Stuart Mill, who-although he did not always sympathise with the Italian's advocacy of revolutionary methods - openly acknowledged his 'highest admiration for Mazzini'. And the arguments of the liberal nationalists received a strong endorsement in Mill's major works, most notably his Considerations on Representative Government (1861).

Mill defined a nation in terms that were explicitly political. He wrote:

A portion of mankind may be said to constitute a Nationality if they are united among themselves by common sympathies, which do not exist between them and any otherswhich make them cooperate with each other more willingly than with other people, desire to be under the same government, and desire that it should be government by themselves or a portion of themselves, exclusively. (Mill, 1963, p. 1759)

He went on to say that 'where the sentiment of nationality exists in any force, there is a prima facie case for uniting all the members of the nationality under the same government, and a government to themselves apart'. He justified this assertion in the next sentence: 'This is merely saying that the question of government ought to be decided by the governed'. 
The principle of nationality was, in other words, a clause of liberalism itself: 'It is in general a necessary condition of free institutions, that the boundaries of governments should coincide with those of nationalities'. Obviously, that 'necessary condition' did not apply to 'Nations that are still barbarous', which ought to be 'conquered and held in subjection by foreigners' as that could '[carry] them rapidly through several stages of progress'. But they too would ultimately be in a position to merit a government whose boundaries aligned with their nation and so have a self-determining state of their own.

\section{The mid-century turn}

These were all worthy sentiments. Unfortunately, high-mindedness has never been a recipe for political success. A movement of intellectuals that entirely lacked a popular base, liberal nationalism's culminating moment, the European revolutions of 1848 ended in utter failure. And as each of those revolutions collapsed, the principle of nationality experienced a far-reaching illiberal turn.

That sea change reflected the myriad trends that were dramatically reshaping the economic, social and political landscape, and that became ever more pronounced as the century unfolded.

Perhaps the most directly relevant of those trends was the rise of mass politics. Almost everywhere, rapid urbanisation, rising literacy and the development of an inexpensive, mass circulation press disrupted traditional patterns of deference and subordination while bringing ever greater numbers into politics. At the same time, the emergence of new forms of transport and communication undermined the geographical segmentation of political life and increased its pace and intensity. As The Times of London noted in 1859, whereas elections used to drag on for months, 'now, the phases of the contest succeed each other with startling rapidity'and even more important, thanks to instantaneous communications:

electors are no longer confined to the communications of their own candidate: they can peruse, contrast and criticize a dozen addresses at a time and deduce perhaps rather a broader moral than any particular candidate intended to convey. (The Times, London, 11 April 1859)

The result was to make the old politics of patronage less viable, provoking a shift toward politics based on parties, promises and programs; however, the promises and programs typically involved an expansion in the activities undertaken by governments, broadening the range of people whose lives were significantly affected by political choices and who, as a consequence, could be mobilised to political ends. 
This was not merely a question of ordinary citizens; rather, as governments took on wider responsibilities, the numbers they employed burgeoned, giving rise to a constituency whose livelihoods depended directly on the political process. The move, throughout continental Europe, to armies based on mass conscription further boosted the size of that constituency, not least by creating an expanding stratum of commissioned and non-commissioned officers recruited from the middle class and the petty bourgeoisie that was perpetually entangled in a conflict with the stillpowerful component of the officer corps that had aristocratic origins.

While all that would certainly have been enough to point nationalism in new directions, a complex of far-reaching economic and social shocks added fuel to the fires. In particular, as an integrated world economy came into being, what is now often referred to as the first globalisation led to the rapid expansion of international trade, causing massive shifts in the terms of trade, increasing competitive pressures and igniting calls for a return to protectionism.

At the same time, global capital flows also grew greatly, making economies more vulnerable to severe financial crises, which they were incapable of cushioning or correcting.

And last but not least, as population growth accelerated, and the costs and risks of long-distance transport fell, there was a staggering increase in the international movement of people: between 1815 and 1914, some 82 million people migrated of their own free will from their place of origin to a distant point, undermining traditional societies and bringing into contact people with vastly different cultures, languages and expectations (Osterhammel, 2014). Exacerbating the tensions that caused was the fact that the people on the move were not solely European: just from the port of Hong Kong, over 500,000 Chinese left between 1854 and 1880, bound for the already conflict-prone (and at times entirely lawless) mines, goldfields and railroad beds of the countries of recent settlement.

Compounding the pressures those shocks created was a step-rise in the reach and intensity of competition and conflict between states. That was partly due to the scramble for colonies: between them, the European powers controlled 35 per cent of the landmass of the planet in 1800; by 1878 that share had grown to 67 per cent; in 1914, it reached an extraordinary 84 per cent (Nester, 2010). However, it also reflected changes in the nature of warfare that steadily increased its costs, placing enormous pressures on the Russian, Austro-Hungarian and Ottoman empires, which lacked the fiscal capacity to bear the resulting financial burdens. As they responded by increasing the taxes they demanded - inefficiently and ineffectivelyfrom their subject populations, the tensions within those empires became ever more acute, weakening their grip and profoundly destabilising the world system. 
But the metamorphosis_ - or one might say metastasis_of nationalism was not solely the result of the period's economic and social transformations. Rather, it was also profoundly influenced by far-reaching changes in social thought.

However one characterises them, those changes did not form a tidy package. On the contrary, they bundled together disparate approaches that scarcely sat together easily, and were in some cases facially inconsistent.

There was, for example, a renewed worship of tradition and a longing to restore an entirely mythical past in which communities had supposedly lived in organic harmony, in an idyll suffused by a Herderian glorification of the Volk. Yet there was also a cult of the will that asserted that life was struggle, that the struggle was between competing human groups, and that victory in the unforgiving battle would go to those groups that were most disciplined, most ethnically homogenous and hence most united.

Equally, there was an entirely new emphasis on the irrational, and on both the risks it posed-notably in the form of the mob-and on the scope it created for charismatic leaders to manipulate the masses into motion. Yet, at the same time, there was supreme confidence in the potential scientific methods offered to manage human populations, culling out the degenerate elements and promoting those that were 'sound', as well as to more broadly solve social problems and control the course of history.

Perhaps the term that best captures this potpourri is vitalism-the belief that there is a volcanic energy at work in human affairs that is simultaneously ever menacing and ever capable of being harnessed. The point is not that vitalism was a conceptual mess; looked at synoptically, the thinking of every era is. Rather, what matters is that it offered a menu of elements that could be assembled and deployed in varying proportions.

When that possibility was put together with the diversity of circumstances, the result was a proliferation of types of nationalism with greatly differing emphases and social bases. At least four are worth mentioning.

There was, to begin with, reactionary nationalism. This was the nationalism of the cult of tradition, which sought either to preserve or recreate pre-modern hierarchies of rule. Perhaps its most illustrious proponent was Sergius Uvarov, who, in 1833, as the Tsar's newly appointed minister of education, framed the official state philosophy of Nicholas I in the famous trilogy of 'Orthodoxy, Autocracy and Nationality'. An urbane and effective apologist for the anti-Enlightenment, Uvarov fought Cartesianism and scepticism with a new ideology that often seems to anticipate modern totalitarianism in its mystical reverence for the leader and its obsession with obedience, submission and loyalty. 
No less complex was the nationalism of the modernising autocrats, with Bismarck devising an approach adopted in late nineteenth-century contexts that ranged from that of the great Ottoman sultan, Abdülhamid II (and his worthy twentieth-century successor, Mustafa Kemal Ataturk) at one end of the globe to Ito Hirubumi and the oligarchs of Meiji Restoration Japan at the other. Driven by the determination to rival the great powers, those autocrats typically built coalitions that united elements of the landed or feudal aristocracy with the most dynamic sections of the industrial and commercial bourgeoisie, using economic and political nationalism as the cement that held the coalitions in place.

A quite different social base underpinned what might be termed populist nationalism, which invariably turned its fire primarily on the enemy within. Andrew Jackson was undoubtedly its pioneer, with his appeal to 'the productive and burden-bearing classes'. That appeal combined a relentless attack on 'the money power' of the eliteswho he portrayed as a morbid growth on an otherwise healthy and democratic body politic - and an implacable hostility to the American Indians. Mobilising the land-hunger of a population of frontier farmers who required constant new supplies of cheap land to enable their numerous offspring to reproduce their ways, the Jacksonians set the template for a style of politics that galvanised mass constituencies which felt squeezed from above and menaced from below.

Last but by no means least was the separatist nationalism of ethnic minorities, which emerged primarily in the great land empires. Precisely because it was born from an acute resentment of those empires' dominant cultures, it was perhaps the most virulent of the lot, degenerating - most obviously in Serbia and Macedonia-into murderous violence. Moreover, because it provoked the rise of a counter-nationalism, in which the empires sought to impose and entrench the dominant culture, it triggered a vicious cycle that converted resentment into hatred and violence into savagery. To a considerable extent, a similar pattern played itself out in Ireland, although it was only after the First World War that it reached the pitch the Serbian and Macedonian conflicts had attained by the 1890s.

There were, of course, other nationalisms too; for example, the emergent nationalism of the Indian National Congress. But what these four varieties shared was an intense exclusionary streak. That had, of course, been a factor in the American Revolution and even more so in the French Revolution, with the Jacobins coining the concept, which went on to have an unspeakably grim career, of 'enemy of the people'. However, what was especially pronounced in the exclusionary streak of the post1850 nationalisms was that it targeted entire groups, variously defined by religion, ethnicity or race. 
Thus, even Bismarck, who was more moderate than most, ordered the deportation of around 30,000 Polish aliens—including some 10,000 Jews-from Prussia, as part of his more general plan to create a German Empire in which German was the sole language and Protestantism the main religion.

A no less striking case is that of Theodore Roosevelt, an ardent reformer who regarded himself as a Progressive. Roosevelt advocated what he considered to be racial hybridity, believing that the world's most accomplished 'races'- the British, the Americans and the Australians - drew their strength from the merging together of diverse and complementary racial strains. And he celebrated war because he viewed it as a crucible whose constant stresses and dangers would generate pressures on those 'races' to unify into a single, exemplary, race. Yet the crucibles of the 'New Nationalism' that Roosevelt championed were invariably racially discriminatory. They always, and deliberately, excluded one or more races-usually blacks, Asians and American Indians-because Roosevelt believed that in the absence of rules that kept those races in their place, 'indiscriminate mixing' would inevitably lower the superior race's intelligence, morals and courage.

Finally, adding to the pattern of exclusion, new and particularly vicious forms of anti-Semitism began to gain mass appeal virtually everywhere, ominously warning of the horrors that were to come.

Overall, the triumphant nationalisms of the era were nationalisms of closure: closure from threatening imports, closure from alien populations, closure from the cultures of the rest of the world.

\section{The British exception?}

In short, the world of the 1890s was awash in deeply illiberal, and often positively repellent, nationalisms. Yet Britain itself seemed an exception.

It and it alone, one might have thought, had heeded the warning of that great liberal, Lord Acton, that the principle of nationality, far from being an ally of liberty, was directly opposed to it. It was, he wrote barely a year after Mill's Considerations had endorsed the principle, both revolutionary and despotic in character, because it makes 'a single definite object', the glory of the nation, 'the supreme end of the State', rather than recognising the necessary plurality of objectives in a free country. And in the conclusion of his magnificent response to Mill, Acton set out one of the standing beliefs of classical liberalism:

The co-existence of several nations under the same State is a test, as well as the best security of its freedom. It is also one of the chief instruments of civilisation; and, as such, it is in the natural and providential order, and indicates a state of greater advancement than ... national unity. (Dalberg-Acton, 1948, p. 185). 
To say those words had moral authority in Victorian Britain is not to ignore the many points of frictions: what was invariably called the 'Irish question' in the UK itself; the nagging issue of Québec in Canada; and the rebellious Boers in South Africa. But unlike its continental counterparts, Britain did not face an immediate fiscal crisis; it was therefore never forced-as were the Russian, Austro-Hungarian and Ottoman empires in the second half of the nineteenth century-to intensify revenue extraction from its dependent territories, converting frictions into revolts those empires entirely lacked the resources to manage. Moreover, at home, Britain's relative prosperity had allowed it to avoid the type of closure that was occurring elsewhere.

But it would be wrong to underestimate the mounting tensions. These were partly internal. The sheer length of Queen Victoria's reign — from 1837 to 1901—had almost certainly made it easier for many British and even Irish men and women to feel a sense of stability and continuity despite an unparalleled rate of urban, demographic and technological change; but as the Victorian era approached its end, social conflict became significantly more intense, even though it remained less menacing than on the continent.

However, what was most striking and in many respects novel was the anxiety that gripped the elite about their country's future. The British, it is well known, had been belligerently patriotic, if not positively chauvinistic, in the Napoleonic wars and their immediate aftermath. But as the threats receded, the British patria, which had figured so prominently in the battles between Whigs and Tories in the century to 1820 , virtually disappeared as a political issue. Of course, patriotism remained as a generic label for all kinds of national self-reproach, self-approbation and identification. Yet with the exception of Disraeli, the leading politicians neither adopted a nationalistic perspective nor suggested Britain's pre-eminence, much less its survival, was ever in question. It seemed as if Britannia pre-eminent had inoculated herself against a nineteenth-century epidemic.

But as the decades passed, an almost endless list of new fears emerged and moved to the centre of politics. In a country whose intelligentsia was obsessed with 'national character', the belief developed that the admirable amalgam of John Bull and Mr Podsnap was threatened by 'race suicide', as rising income levels relaxed the constraints of natural selection and allowed the genetically inferior urban underclass to out-breed its betters. At the same time, free trade no longer seemed to be fair trade, and with Britain's industries struggling to achieve the economies of scale enjoyed by the great American trusts and the German combines, there was widespread concern about economic decline. And compounding all that was the perception that the Empire, which now stretched from one end of the globe to the others, might be simply impossible to defend.

Britain was, in Joseph Chamberlain's evocative phrase, a 'weary titan', staggering 'under the too vast orb of its fate'. 
No one better synthesised those fears than Sir Charles Dilke, the radical liberal who served as Under-Secretary of State for Foreign Affairs during Gladstone's second government. In his immensely influential Problems of Greater Britain, which was published in 1890, Dilke framed the problem squarely in terms of the ability of the rising colonies to take over the responsibilities that until then had been borne by the mother country. 'The danger in our paths', he wrote, is 'that the enormous forces of European militarism may crush the old country and destroy the integrity of the Empire before the growth of the newer communities, which it contains, has made it too strong for the attack' (Dilke, 1890, p. 6).

Among the many, often contrasting, views as to how to deal with that danger there were two common themes. The first was that there had to be a quest for what came to be known as 'national efficiency' and which ultimately involved everything from eugenics to the promotion of larger, more concentrated industries. The second was that the external casing of the Empire needed to be strengthened by some form of 'imperial preference', and its internal arrangements revised in a manner that gave the settler colonies both much greater responsibilities and much greater weight.

Overall, the time seemed to have come that had been predicted by Herman Merivale, who as Under-Secretary of State at the Colonial Office from 1847 to 1860 had shaped the theory underpinning the Empire. Sooner or later, he had said, there would dawn a day when, 'by the gradual relaxation of the ties of dependence' between the settler colonies and the mother country, 'the crown [would] remain, at last, in solitary supremacy, the only common authority recognised by many nations [that are] politically and socially distinct' (Merivale, 1967, p. 673). And when that day arrived, the Empire would have to prove flexible enough to absorb the 'great Australian Republic which probably is to be'.

\section{Conclusions}

The nation-state is one thing; its cult another. But by 1890 , the spread of the latter had, for better or worse, helped bring about the triumph of the former: in the century and a bit that separated that date from the American Declaration of Independence, the principle of nationality had only gathered strength, propelling the rise of the nation-state in its wake. The open question was not whether the nation-state would continue its ascendancy but precisely what form it would eventually take in those parts of the world where its victory as the natural way of organising the polity was not yet complete. As far as the dominions were concerned, the 'National Policy' that had swept John MacDonald back to the Prime Ministership of Canada in 1878, and that emphasised Canada's future as an integrated continental power, must have seemed like an attractive option. And in many respects that was the option the Australian colonies adopted in 1901. Were there viable alternatives? Would they have yielded better outcomes? 


\section{References}

Burke, E. (1852). The works and correspondence of the Right Honourable Edmund Burke (C. William \& R. Bourke, Eds). Henry G. Bohn.

Dalberg-Acton, J.E.(1948). Essays on freedom and power. The Beacon Press.

Dilke, C.W. (1890). Problems of Greater Britain (Vol 1). Macmillan.

Herder, J.G. (2004). Another philosophy of history and selected political writings (I.D. Evrigenis $\&$ D. Pellerin, Eds). Hackett Publishing.

Kant, I. (2006). Anthropology from a pragmatic point of view (R. Louden, Ed.). Cambridge University Press. (Original work published 1797.)

Merivale, H. (1967). Lectures on colonization and colonies delivered before the University of Oxford, 1839, 1840 \& 1841 and reprinted in 1861. Frank Cass. doi.org/10.1017/ cbo9780511722370.

Mill, J.S. (1963). Letter to Peter Alfred Taylor. In Collected Works ofJohn Stuart Mill (Vol. 17; J.M. Robson, Ed.). University of Toronto Press.

Nester, W.R. (2010). Globalization. A short history of the modern world. Palgave Macmillan.

Osterhammel, J. (2014). The transformation of the world: A global history of the nineteenth century. Princeton University Press.

Paine, T. (1776). Common sense [Project Gutenberg edition: 24 June 2017]. www.gutenberg. org/files/147/147-h/147-h.htm.

Reiss, S.H. (1955). The political thought of the German Romantics, 1793-1815. Oxford University Press.

Rousseau, J.-J. (2001). Letter to Beaumont, letters written from the mountain, and related writings (C. Kelly \& E. Grace, Eds; C. Kelly \& J.R. Bush, Trans.). University Press of New England.

Scott, J.B. (1916). Preface. In E. de Vattel, Le droit des gens ou principes de la loi naturelle Appliqués à la conduite et aux affaires des Nations et des Souverains par M. de Vattel [The law of nations: Or, principles of the law of nature applied to the conduct and affairs of nations and sovereigns] (Vol. I; Reproduction of Books I and II of 1758 edition). Carnegie Institution. archive.org/details/ledroitdesgensou01vattuoft.

Varouxakis, G. (2018). Cosmopolitanism and internationalism in modern British political thought: Continuities and discontinuities. In D. Gusejnova (Ed.), Cosmopolitanism in conflict: Imperial encounters from the Seven Years' War to the Cold War (pp. 147-178). Palgrave Macmillan. doi.org/10.1057/978-1-349-95275-5_6. 
This text is taken from Agenda, Volume 27 - Number 1, 2020, edited by William Coleman, published 2020 by ANU Press, The Australian National University, Canberra, Australia.

doi.org/10.22459/AG.27.01.2020.05 